that the slime-glands were much less developed in the males than in the females.

The structure of the female organs in our Caracas species agrees pretty well with Prof. Hutton's drawings ( $A n n$. and Mag. of Nat. Hist., iv. ser., vol. I8, pl. xvii., fig. 8) ; but I am not prepared to accept his interpretation. The following sketch will give an idea of what I saw.

Moseley's Fig. I on PI. 1xxiv. is very different from the shape of the ovary in our species; nor can I well understand the existence of ova on the outside of the ovary as they appear in his drawing. The ovary in $P$. Edwardsii is rather long, and abundantly covered by fine tracheal tubes, with the exception of a narrow zone close to the branching out of the oviducts. I could not satisfy myself as to its being divided by a septum, nor could I find any ova in it; most likely it is not now the right time. At a very short distance from the beginning of the oviducts there is a kind of obtuse cacum on each of them, which is followed by a spherical body covered by tracheal tubes. These bodies are the organs described by Prof. Hutton as testes.

There is however in our species no trace of what he takes for vasa deferentia, the spherical body adhering directly to the oviduct. Its wall is of considerable resistance, and bursts only under great pressure, giving issue to an immense number of thin rod-like corpuscula, which soon after begin to move slowly in the surrounding water. They are of course spermatozoa which have lost their nuclei, and the spherical body can therefore be nothing else but a receftaculum seminis.

The oviducts of three specimens which I dissected contained very few embryos; in one there was only one in each oviduct, in the others there were two. They were fully developed, and occupied the part of the oviducts close to the vulva. It would appear from this that the time of reproduction is now almost over; further observations will show whether there is really such a periodicity in our species.

It is probable that the oviducts of $P$. Edzuardsii never present the shape of string; of sausages, as seen by Mr. Moseley in $P$. Capensis, the embryos being so considerably larger.

Animals thrown alive into alcohol pour forth from their slimeglands first the viscid substance contained in these ; then there comes out a slightly reddish matter, which dissolves in the alcohol, giving it the same colour.

With respect to all other points I can only confirm $\mathrm{Mr}$. Moseley's statements. 1 keep alive a colony of Peripatus of both sexes in the hope to have once a chance to observe the copula.

I cannot conclude these remarks without confessing that I am not at all quite sure whether our Peripatus is really $P$. Edzuardsii, as the figure of this species in Nicholson's "Manual of Zoology" (5th edit. p. 315), which is said to be after Grube, does not agree well with my living specimens. Grube's original paper I cannot consult here. It may be however that he made his drawing from a contracted alcoholic specimen. A. ERNS'

The University, Carácas, January 16

\section{ACOUSTICS IN CHINA}

THE following letter to Prof. Tyndall has been sent to us for publication by the writer, Mr. Fryer. It will be seen that a really scientific modern correction of an old law has singularly turned up from China, and has been substantiated with the most primitive apparatus. Dr. W. H. Stone, to whom the letter has been submitted, has kindly appended a note.

To Prof. Tyndall, Ll.D., F.R.S., \&c.

DEAR SiR,-My friend Mr. Hsii has brought some interesting facts relating to acoustics before my notice. As he is the father of the native official who translated with me your work "On Sound," and as he refers particularly to that work, I venture to forward you a translation of his remarks, in the hope that you will satisfy his mind on a subject in which he takes such deep interest. He says :-

"In ancient Chinese works on music it is stated that strings or pipes produce an octave or twelve semitones higher or lawer by halving or doubling their length.

"In a work written during the Ming dynasty by Chen-toaiyoh it is stated that this rule will only hold good with strings, but not with open pipes such as the flute or flageolet.

"Some years ago I tried to investigate the cause of this difference and its exact amount. A round open brass tube, say nine inches long, gave a certain note by pressing the end of it against the upper lip and blowing through an embouchure made there. Cutting off half the tube, the remaining four and a half inches would not sound the octave; but by cutting off half an inch more, thus leaving four inches in length, the octave was sounded accurately. This experiment was tried on tubes of various lengths and diameters with a similar result, viz. that four-ninths of the length always sounded the octave more or less exactly. Looking at a foreign keyed flute I noticed the same principle carried out in the arrangements for producing octaves. I could not however see the reason why open pipes should not follow the same rule as strings and closed pipes.

"When I read the translation of Prof. Tyndall's treatise 'On Sound,' I was surprised to find the old Chinese idea strictly maintained. It says (p. 214): 'In both stopped and open pipes the number of vibrations executed in a given time is inversely proportional to the length of the pipe,' \&c. According to this, as the octave of any note has to execute exactly double the number of vibrations in a given time, an open pipe ought to be exactly halved to make it sound an octave higher. This I have shown to be erroneous by my experiments.

"Fearing that I have misunderstood the English professor's meaning, $X$ beg that he may be written to on this subject, and that my doubts may be thereby cleared up. What I want to know is the exact proportion in length that exists between any open pipe and a pipe of similar diameter sounding its octave higher. Also the exact proportions in length for each of the open pipes sounding the twelve semitones which form a scale of one octave. If the length forming the octave in open pipes does not agree with the length for strings or closed pipes, then the lengths of all the pipes giving intermediate notes must also differ. How are these lengths to be calculated? Can they be expressed by any mathematical curve or formula? Why does not the same rule hold good for open pipes as for strings or stopped pipes? I have a theory of my own, but I do not feel sufficient confidence in myself to make it public until I have bestowed more thought and attention upon it. In the meantime I shall be glad if any foreign scientists can enable me to understand this interesting and important subject. The theory and practice of music in China has gradually become vitiated through errors in the construction of musical instruments, and I am therefore desirous of having a scientific basis upon which a reformation may be effected."

There is no treatise on music or acoustics that $I$ can find which throws any light on these interesting questions, and I shall therefore deem it a great favour if you will direct me to any work that will enable me to satisfy the eager inquiries of my native friend.

I send by book-post a pamphlet for your kind acceptance, containing an account of the Department for the Translation of Scientific Books at the Kinagnan Arsenal. You will see that your " Notes on Light" are now published in Chinese. A copy will be forwarded to you shortly. Your " Heat a Mode of Motion" I hope to begin to translate at no very distant time. Your "Notes on Electricity" in (hinese will be published shortly.

$$
\begin{aligned}
& \text { I remain, dear Sir, yours faithfully, } \\
& \text { Shanghai, June I, I880 FRYER } \\
& \text { November } 25 \text { th, 1880 }
\end{aligned}
$$

P.S.-I have sent a copy of this letter to the Editor of NATURE, and shall feel greatly obliged if you will forward your reply, if any, to him for publication.-J. F.

MR. FRYER is perfectly correct in his observations. You will find the explanation and formula needed at p. I67 of my little book on Sound, under the heading "Correction of Bernouilli's Law." "It has long been known," I there say, "that if an open pipe be stopped at one end its note is not exactly an octave below that given by it when open, but somewhat less, the interval being about a mojor seventh instead of an octave."

Then follows the mathematical statement, from which the corrections needed by Mr. Fryer could easily be obtained. M. Bosanquet's excellent experimental investigation of the subject is briefly described. His results give the correction for the open end of the pipe as 635 of radius of pipe, and $59 r$ for the mouth. Mr. Bosanquet remarks that in Bernouilli's theory the hypothesis is made that the change from the constraint of the pipe to a condition in which no remains of constraint are to be perceived takes place suddenly at the point where the wave system leaves the pipe. It is however evident that the diverg. ence which takes place may be conceived of as sending back to the pipe a series of reflected impulses, instead of the single 
reflected impulse which returns from the open end of the pipe according to Bernouilli's theory, and that these elementary im. pulses, coming from different distances, may be altogether equivalent to a single reflected impulse from a point at a little distance from the end of the pipe. It is not a little interesting that a confirmation of this little-known fact should have come from so far off, and have been obtained by such simple experimental means.

I4, Dean's Yard, S.W., January 8

\section{SCIENTIFIC SERIALS}

Annalen der Physik und Chemie, No. I3, I880.-On currents of motion in polarised platina, by H. Helmboltz, - On the course of polarisation currents, by A. Witkowski.-On the changes of form and volume of dielectric bodies wrought by electricity, by W. C. Köntgen.-On Lichtenberg figures and electric valves, by W. von Bezold. - On the electromotive forces of some zinccopper elements, by Fr. Fuchs.- On the measurement of electric conductivities, by $\mathrm{G}$. Kirchhoff,-Some experiments on induction in conductors, by F. Himstedt.-On the discharge of electricity in rarefied gases, by E. Goldstein.-On the production of har monic tones through vibrations of a fundamental tone, by $R$. Koenig,-Researches on the law of dispersion, by $\mathrm{O}$. Hesse.On fluorescence, by S. Lamansky.-On the law of heat-radia. tion and the absolute emission-power of glass, by I. Graetz.On annealing of steel and measurement of its hardness, by $V$. Strouhal and C. Barus.-On the height of the atmosphere (continued), by A. Ritter.-Researches on the volume-constitution of liquid compounds, by $\mathrm{H}$. Schröder.-- On variations of the sea-surface by reason of geological changes, by K. Zöppritz. -On the theory of Volta's fundamental experiment, by $F$. Exner.-The theory of the galvanic element, by the same.Note on the quantities of heat carried away by currents of an unequally heated liquid, by A. Oberbeck.-Note on Herr Sienens' recent paper on electric conductivity of carbon and temperature, by J. Borgmann.

No. I, I881. - New researches on Newton's rings, by I. Sohncke and A. Wangerin.-On vapour tension of homologous esters, by O. Schumann.-On the elasticity and the electric conductivity of carbon, by W. Beetz.-Thermal theory of the galvanic current, by J. L. Hoorweg.-On electric light phenomena in gases, by E. Goldstein.-On the phenomena of glow at metallic electrodes within a hydrogen atmosphere of varying pressure, by O. Lohse.-Note on Riecke's paper on the electric elementary laws, by H. Lorberg.-Clausius' law and the motion of the earth in space, by J. Fröhlich.-On the application of the proposition of the virial in the kinetic theory of gases, by H. A. Lorentz. - On the influence of expansion of molecules on the pressure of a gas, by D. J. Korteweg.-On the velocity of light in various quartz surfaces, by W. Hallock.-Reply to Herr Darn, by $\mathrm{E}$. Edlund.-On tones arising through intermittent radiation on a gas, by $W$. C. Röntgen.-On phenomena of diffraction before the border of a screen, by O. Tumlirz.

THE Fournal of Physiology, vol. iii. No. 2, January, contains : Dr. S. H. Vines, on the proteid substances contained in the seeds of plants. To this important paper is appended a classification of aleurone grains and a classified list of the plants whose seeds were examined.-Dr. Sydney Ringer, the influence of season and of temperature on the action and on the antagonisms of drugs.-Dr. C. S. Roy, the elastic properties of the arterial wall, with plates v.-vii.-Dr. J. Ott, on crossed hyperæesthesia, and notes ox inhibition.

Fournal of the Royal Microscopical Society, ser. ii. vol. i. part I, February, contains : Dr. C. T. Hudson, on Ecistes janus and Floscularia trifolium, two new species of Rotifers (plates $\mathbf{I}$ and 2), and the usual summary of current researche relating to zoology and botany, microscopy, \&c.-The minutes of the proceedings of the Society are given at the end of the part.

Fournal of the Franklin Institute, February.-On the revolu. tion of a fluil ellipsoid with three unequal axes, by T. Craig.A newly-discovered property of the ellipse, and its application to the "oval chuck," by F. M. Leavitt. -A simple-transmissiondynamometer, by $\mathbf{E}$. Thomson.-Methods for judging of the wholesomeness of drinking-water, by R. Haines.-The basic dephosphorising process, by J. Reece.-Riehla Brothers' improved vertical testing machine, 50,000 pounds capacity.
Tне American Naturalist, February, I88I.-L. F. Ward, incomplete adaptation as illustrated by the history of sex in plants. - Sarah P. Monks, a partial biography of the green lizard. - G. K. Morris, a new leaf-cutting ant.-S. V. Clevenger, comparative neurology (continued). - Justin Spaulding, the bee's tongue, and glands connected with it. -Wm. E. Doyle, history of the buffalo.

Revue Internationale des Sciences biologiques, January $\mathrm{r}_{5}, \mathrm{r}_{88} \mathbf{r}$. -Prof. Hanstein, protoplasm considered as the basis of animal and vegetable life.-D. Debierre, an introduction to the earth's history.-Ch. Letourneau, the ethics of egoism (Schopenhauer's "Aphorisms on Moderation in Life").-J. L. de Lanessan, digestion in vegetables.

The Proceedings of the Linnean Society of Nere South Wales, vol. iv. part 4, Sydney, 1880.- John Brazier, synonomy of, and remarks upon, Port Jackson, New Caledonian, and other shells, with their distribution; list of land-shells found on Thursday Island, with description of new species ; Port Jackson and New South Wales brachiopods; mollusca recently dredged at Port Jackson Heads; on the locality of Oniscia ponderosa.-E. P. Ramsay, on an undetermined species of Lalage ; contribution to the zoology of New Guinea, part 6.-W. A. Haswell, supple mentary note on Australian Leucosiidre; on Australian Brachy. ura Oxyrhyncha, plates $25,27:-C$. Jenkins, on the geology of Yass Plains (3).-W. Macleay, on the Mugilidæe of Australia.C. S. Wilkinson, on the Abercrombie caves.

Journal of the Astatic Society of Bengal, vol. xlix. part 2, No. 2, August 30, I880, contains :-Alexander Pedler, on the past and present water supplies of Calcutta. - R. Lydekker, on the zoological affinities of the bharal or blue shesp of Tibet. While forming a very closely connecting link between the sheep and the goat; the author thinks it cannot be referred to either of the genera Ovis or Capra, and that Hodgson's genus Pseudovis should be retained for its reception.--\}. Wood-Mason, on a new butterfly (Hebomoia Roepstorfii) from South Andaman, near $H$. sulphurea, Wallace.

Fournal de Physique, February:-On radiophony, by E. Mercadier.-Researches on the differences of potential of two metals in contact; results, by H. Pellat.-Dr. Cusco's lens with variable focus, by C. M. Gariel.-On the correction of cooling in calorimetry, by M. Berthelot.-Edelmann's universal support for physical experiments, by A. Terquem.

\section{SOCIETIES AND ACADEMIES LONDON}

Zoological Society, March 1.-Prof. W. H. Flower, F.R.S., president, in the chair.-The Secretary exhibited the cast integument of a large spider (Mygale bistriata?) which had been shed in the Society's Gardens.-Mr. G. E. Dobson, C.M.Z.S., read a paper on the anatomy of the family Erinaceide, commencing with that of the curious and rare form Gymnure Raffesii, with which the species of Erinaceus were compared. Gymnura was shown to be a peculiarly central form, the survivor probably of a once widely-spread group. Altogether the anatomy of thirteen species of Erinaceidæ was treated of in this paper.-A communication was read from Mr. F. Moore, F.Z.S., containing the descriptions of some new genera and species of Asiatic nocturnal lepidoptera. The characters of I 50 new species were given, representing eighty-two genera, of which twenty-nine were new to science. - A communication was read from $M r . R$. Collett, C.M.Z.S., containing an account of the breeding habits of the grey seal (Halichoerus grypus), as observed on the Fro Islands, off Trondhjem's Fiord, in Norway.-Mr. R. Bowdler Sharpe, F.Z.S., read a note on the fantail flycatcher of Western Australia (Rhipidura presssi), of which he had lately had for the first time an opportunity of examining a specimen.

Geological Society, February 23.--Robert Etheridge, F.R.S., president, in the chair.-William Henry Goss was elected a Fellow of the Society.-The following communications were read:-A letter from Dr. John Kirk, communicated to the Society by the Right Hon. Earl Granville, dated H.M. Agency and Consulate General, Zanzibar, December 20, 1880. "It may be of interest to record the occurrence here of an earthquake shock felt in the island of Zanzibar at $6.58 \mathrm{a.m}$. mean time, on the morning of the I8th inst. Although the shock was very distinct no damage appears to have been done to any buildings in town. It is now twenty-four years since a similar shock has been here noticed; but on the mainland, espe- 